\title{
Diagnosis of Dengue by Using Reverse Transcriptase- Polymerase Chain Reaction
}

\section{Marize Pereira Miagostovich/ ${ }^{+}$, Flávia Barreto dos Santos, Eliane Saraiva M de Araújo, Juarez Dias*, Hermann G Schatzmayr, Rita Maria Ribeiro Nogueira}

Laboratório de Flavivírus, Departamento de Virologia, Instituto Oswaldo Cruz, Av. Brasil 4365, 21045-900 Rio de Janeiro, RJ, Brasil *Divisão de Vigilância Epidemiológica, Secretaria de Saúde do Estado da Bahia, Salvador, BA, Brasil

A rapid identification of dengue viruses from clinical samples by using a nested reverse transcriptasepolymerase chain reaction (RT-PCR) procedure was carried out for diagnostic and epidemiological purposes. RT-PCR identified DEN-1 and DEN-2 viruses in 41\% (41/100) of previously confirmed cases and provided an accurate confirmation of DHF in four fatal cases. RT-PCR was also useful for detecting and typing dengue viruses in suspected cases, allowing a rapid identification of new serotypes in endemic areas.

Key words: dengue - diagnosis - virological surveillance - polymerase chain reaction

Dengue virus activity increased significantly in Brazil after the introduction of dengue virus type 1 (DEN-1) into the State of Rio de Janeiro in 1986 (Schatzmayr et al. 1986). DEN-1 was the only serotype circulating in the country until 1990, when dengue virus type 2 (DEN-2) was also introduced (Nogueira et al. 1990). During the last decade, dengue epidemics have been recorded annually in the country and the number of reported cases has shown dengue infection to be an increasing public health problem (Figueiredo 1996)

The circulation of dengue viruses in the Americas, including dengue virus type 3 (DEN-3) which reappeared in the region (Nicaragua and Panama) in 1994 (CDC 1995) after an absence of 16 years, represents a real threat of new dengue epidemics in the country. Since a dengue vaccine is still being developed, an active surveillance system is the key to early detection and prevention of large epidemics. The availability of a rapid, sensitive and specific method to detect dengue virus infection is one of the most important factors necessary for that purpose.

The laboratory diagnosis of dengue virus is based primarily on virus isolation and serology. However the increasing number of reported cases

Supported by CNPq, Fundação Banco do Brasil and COLAB, Ministry of Health.

${ }^{+}$Corresponding author. Fax: + 55-21-270.6397. E-mail: marizepm@gene.dbbm.fiocruz.br

Received 10 March 1997

Accepted 16 June 1997 of dengue fever/dengue haemorrhagic fever (DF/ DHF) in Brazil (Nogueira et al. 1993, Zagne et al. 1994, Souza et al. 1995, Vasconcelos et al. 1995) showed the need for new approaches to diagnosis. Various protocols of polymerase chain reaction (PCR) have offered obvious advantages for the detection of dengue virus (Deubel et al. 1990, Morita et al. 1991, Pao et al. 1992, Seah et al. 1995).

The reverse transcriptase-polymerase chain reaction (RT-PCR) protocol developed by Lanciotti et al. (1992) could detect and identify all four serotypes of dengue viruses simultaneously in a nested procedure. In the present study we employed this protocol for diagnostic and epidemiological purposes. Virological investigation of clinical samples established RT-PCR as an useful tool in the laboratory diagnosis of dengue infections.

\section{MATERIALS AND METHODS}

Clinical samples

Group 1: acute sera from 100 dengue cases previously confirmed by paired serology. All cases were negative for dengue virus isolation. Serum samples were obtained during the dengue epidemic which occurred in the State of Rio de Janeiro in 1995-1996.

Group 2: sera and necropsy tissues from 31 fatal cases suspect of DHF. All clinical samples were obtained from the collection at the Laboratory of Flavivirus, Instituto Oswaldo Cruz, FIOCRUZ.

Group 3: acute sera collected by the epidemiological surveillance system in dengue endemic areas during outbreaks occurred in 1996 in the 
states of Bahia (BA), Rio de Janeiro (RJ) and Espírito Santo (ES).

Virology and serology

Virus isolation was attempted by inoculation into clone C6/36 Aedes albopictus cells (Igarashi 1978) and virus isolates were typed by the indirect fluorescent antibody test using serotype-specific monoclonal antibodies (Gubler et al. 1984).

IgM capture enzyme-linked immunosorbent assay (MAC-ELISA) was performed using a mixture of DEN-1 and DEN-2 antigens according to Nogueira et al. (1992).

\section{RNA extraction and RT-PCR}

Viral RNA was extracted from clinical samples using a silica protocol described previously by Boom et al. (1990).

RT-PCR for detecting and typing dengue viruses was carried out according to Lanciotti et al. (1992). Briefly, cDNA copies of a portion of the viral genome (capsid/prM) were produced and amplified using two consensus primers designed to anneal to any of the four dengue virus types. Second-round amplification with type-specific primers results in different bands of DNA, characteristic for each dengue virus type, that could be observed directly in $1 \%$ agarose gel stained with ethidium bromide. All primers were kindly provided to Dr Vance Vorndam (CDC, Puerto Rico). Positive and negative controls were included in all steps.

\section{RESULTS}

Group 1: fig. shows up the characterization of DEN-1 and DEN-2 viruses by the agarose gel analysis of the amplified products. RT-PCR identified dengue serotypes in $41 \%(41 / 100)$ of cases studied. Eleven DEN-1 and 30 DEN-2 strains were demonstrated in acute sera. Table I shows the RTPCR results according to IgM antibody detection.

Group 2: DHF was confirmed by dengue RNA identification in four cases, two from liver specimens and two from sera (Table II). The remaining cases (27) were negative for virus isolation and RT-PCR on available samples, although eight of them had anti-dengue IgM antibodies.

\section{TABLE I}

RT-PCR ${ }^{a}$ in acute sera negative for virus isolation in C6/36

\begin{tabular}{lcl}
\hline $\begin{array}{l}\text { Anti-dengue IgM } \\
\text { response }\end{array}$ & $\begin{array}{c}\mathrm{N}^{\mathrm{o}} \text { positive/ } \\
\mathrm{N}^{\mathrm{o}} \text { tested (\%) }\end{array}$ & Virus type \\
\hline IgM neg & $19 / 32(59.4)$ & $\begin{array}{l}\text { DEN-1 (4) } \\
\text { DEN-2 (15) }\end{array}$ \\
IgM pos & $22 / 68(32.4)$ & $\begin{array}{l}\text { DEN-1 (7) } \\
\text { DEN-2 (15) }\end{array}$ \\
\hline Total & $41 / 100(41)$ & DEN-1 (11) \\
& & DEN-2 (30) \\
\hline
\end{tabular}

$a$ : Reverse Transcriptase-Polymerase Chain Reaction $b$ : Anti-dengue immunoglobulin $\mathrm{M}$

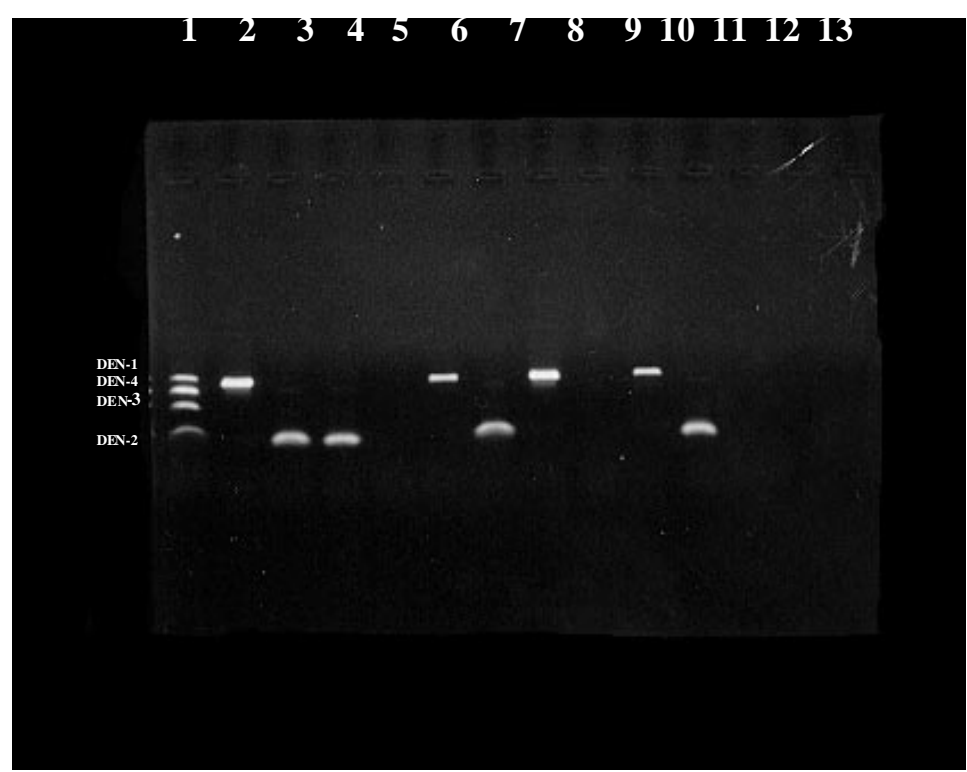

Characterization of DEN-1 and DEN-2 viruses by Reverse Transcriptase-Polymerase Chain Reaction (RT-PCR). Ethidium bromide stained agarose gel showing RT-PCR products: lane 1, molecular weight marker of DEN-1, DEN-4, DEN-3 and DEN-2 RTPCR products corresponding to $482 \mathrm{bp}, 392 \mathrm{bp}, 290 \mathrm{bp}, 119 \mathrm{bp}$, respectively (Lanciotti et al. 1992); lanes 2, 6 and 8, DEN-1 from serum samples; lanes 3, 4 and 7, DEN-2 from serum samples; lanes 5 and 9, negative sera; lane 10 and 11, positive controls of DEN-1 and DEN-2 isolated from Aedes albopictus C6/36 cell line; lane 12, uninfected cell culture; lane 13, water. 
TABLE II

Dengue virus identification in four fatal cases occurring during epidemics in Brazil

\begin{tabular}{|c|c|c|c|c|c|}
\hline Cases & Year/Origin & Clinical samples & $\begin{array}{c}\text { Serotype } \\
\text { identified by RT-PCR } \\
\end{array}$ & $\begin{array}{l}\text { Virus isolation } \\
\text { in } \mathrm{C} 6 / 36 \text { cells }\end{array}$ & Mac-Elisa \\
\hline 1 & 1986/RJ & Liver & DEN-1 & DEN-1 & - \\
\hline 2 & 1986/RJ & $\begin{array}{l}\text { Serum } \\
\text { Liver } \\
\text { Spleen }\end{array}$ & $\begin{array}{l}\text { Nd } \\
\text { DEN-1 } \\
\text { Neg }\end{array}$ & $\begin{array}{l}\mathrm{Nd} \\
\mathrm{Neg} \\
\mathrm{Neg}\end{array}$ & $\begin{array}{c}\text { Pos } \\
- \\
-\end{array}$ \\
\hline 3 & 1996/ES & Serum & DEN-2 & Neg & $\mathrm{Neg}$ \\
\hline 4 & 1996/BA & $\begin{array}{l}\text { Serum } \\
\text { Liver, lung, } \\
\text { kidney, spleen }\end{array}$ & $\begin{array}{l}\text { DEN-2 } \\
\text { Neg }\end{array}$ & $\begin{array}{l}\text { Neg } \\
\text { Neg }\end{array}$ & Pos \\
\hline
\end{tabular}

$a$ : Reverse Transcriptase-Polymerase Chain Reaction; Nd: not done (serum not available); Neg: negative; Pos: positive; RJ: Rio de Janeiro; ES: Espírito Santo; BA: Bahia

Group 3: RT-PCR identified the aetiological agent responsible for three dengue epidemics studied in the states of BA, ES and RJ (Table III). In Bahia this method detected the introduction of DEN-1 into the area. In all opportunities the clinical diagnosis was also confirmed by virus isolation and serology.

TABLE III

Rapid diagnosis by using $\mathrm{RT}-\mathrm{PCR}^{a}$ for virological surveillance

\begin{tabular}{lcc}
\hline Origin & $\mathrm{N}^{\mathrm{o}}$ tested & $\begin{array}{c}\text { Serotypes identified by } \\
\text { RT-PCR }\end{array}$ \\
\hline Rio de Janeiro & 16 & $\begin{array}{c}4(\mathrm{DEN}-1) \\
2(\mathrm{DEN}-2)\end{array}$ \\
Bahia & 6 & $\begin{array}{c}3(\mathrm{DEN}-1) \\
1(\mathrm{DEN}-2)\end{array}$ \\
Espírito Santo & 7 & $2(\mathrm{DEN}-2)$ \\
\hline
\end{tabular}

$a$ : Reverse Transcriptase-Polymerase Chain Reaction

\section{DISCUSSION}

The anti-dengue IgM response and virus isolation using the Ae. albopictus $\mathrm{C} 6 / 36$ cell line have been routinely used for dengue diagnosis in Brazil (Schatzmayr et al. 1986, Figueiredo et al. 1992, Miagostovich et al. 1993, Nogueira et al. 1993, Vasconcelos et al. 1993). However, due to its speed and sensitivity, PCR has been adopted as an alternative method in dengue diagnosis (Laille et al. 1991, Chungue et al. 1993, Morita et al. 1994).

The whole RT-PCR procedure, including RNA extraction, is expensive and requires adequate care in handling the specimens safely, avoiding contamination at all stages. Thus, it should be used mostly on clinical samples from severe forms of infection and in sera obtained from areas recently affected by dengue viruses.

In relation to RNA extraction, we used the silica protocol described by Boom et al. (1990) instead of the method described originally in the RT-PCR procedure (Lanciotti et al. 1992). The elimination of phenol/chloroform extraction and ethanol precipitation has obvious advantages.

Enzyme-linked immunosorbent assay (Elisa) has proven to be a sensitive method for detecting anti-dengue IgM (Nogueira et al. 1992), however a monotypic response is rarely observed because of the extensive cross-reactivity among dengue viruses. In our study, RT-PCR identified dengue virus RNA in $32.4 \%$ and $59.4 \%$ of cases respectively in relation to the presence or absence of antidengue IgM antibodies. Different studies have shown a range from $12 \%$ to $100 \%$ of virus detection in serologically confirmed cases (Chungue et al. 1993, Chan et al. 1994). The inverse correlation between virus isolation and anti-dengue antibodies has been well documented (Nogueira et al. 1992). In agreement with Chan et al. (1994), our results also showed that RT-PCR was most useful when anti-dengue antibodies were undetectable.

RT-PCR provided an accurate identification of dengue virus in four fatal cases. Cases 1 and 2 occurred during a DEN-1 epidemic in Rio de Janeiro in 1986. Case 1 was a 17 year-old male who died seven days after the onset of disease. Liver was the only specimen available $12 \mathrm{hr}$ after death. At that time we isolated DEN-1 virus from the specimen. Dengue virus isolation $40 \mathrm{hr}$ after death was described by Rosen et al. (1989).

Case 2 was a 51 year-old man presenting with the following signs and symptoms: fever, myalgia, diarrhea, hemoptysis, hematemesis, disorientation and progression to shock seven days after 
the onset of disease. At that time demonstration of anti-dengue IgM antibody was a good marker to confirm the clinical and epidemiological diagnosis. RT-PCR was successful in detecting DEN-1 virus in the liver from this patient. Dengue antigen was also demonstrated in liver and lung by using the immunoperoxidase technique (data not shown).

The detection of dengue virus in two liver specimens frozen for ten years suggests that RT-PCR is applicable to retrospective studies. Attempts at RTPCR on formalin-fixed and paraffin-embedded tissues gave unsuccessful results that could be explained by crosslinkage of viral nucleic acid to host proteins caused by formalin fixation (Pearse 1980).

Case 3 was a 52 year-old female presenting fever, cephalgia, arthralgia, rash, petechiae, hematocrit $<45 \%$ and a platelet count of $21,000 \mathrm{~mm}^{3}$ progressing to shock six days after onset of disease. This death occurred during an extensive dengue epidemic in Espírito Santo, where we isolated 25 strains of DEN-2 (data not shown). RT-PCR detected DEN-2 RNA in serum and was conclusive when other methods were unsuccessful.

Case 4 was a 29 year-old male who died when arriving at the hospital. The death occurred in Bahia (Feira de Santana) during an extensive epidemic where 64,435 cases were reported in that state (Secretary of Health, Bahia). DEN-1 (14) and DEN-2 (8) strains were isolated during 1996. Unfortunately clinical data were not available to the laboratory.

Severe forms of dengue infection after DEN-2 virus introduction into Espírito Santo and Bahia was also observed in the states of Rio de Janeiro and Ceará (Nogueira et al. 1993, Zagne et al. 1994, Vasconcelos et al. 1995) showing the hemorrhagic potential of the Jamaican topotype.

RT-PCR was especially useful for monitoring dengue virus activity in endemic areas in Brazil, allowing a rapid identification of dengue viruses in Rio de Janeiro and Espírito Santo. In Bahia we detected the introduction of DEN-1 virus during a DEN-2 epidemic when the local epidemiological surveillance service observed that many individuals were experiencing a second dengue virus infection. Circulation of those serotypes was later confirmed by virus isolation in Ae. albopictus C6/ 36 cells. The whole procedure for isolating and typing dengue viruses in culture cells is time consuming but it is still the definitive system for characterizing dengue viruses.

Taken together our results emphasize the importance of different approaches in dengue diagnosis. RT-PCR data obtained here, confirm this methodology as an important tool for clinical diagnosis and virological surveillance.
Efforts are being made to establish this RTPCR protocol in the National Network of Dengue Laboratories, as an attempt to improve the Dengue Epidemiological Surveillance System, contributing consequently to the current Program of Aedes aegypti Eradication, established by the Brazilian Government.

\section{ACKNOWLEDGMENTS}

To Alice Paiva and Maria Helena Venturini for serum samples from Espírito Santo. To José de Carvalho Filho, José da Costa Farias Filho, Patricia Aila da Costa and José Mariano da Silva for technical assistance.

\section{REFERENCES}

Boom R, Sol CJA, Salimans MMM, Jansen CL, Wertheim-van-Dillen PME, Van der Noordaa J 1990. Rapid and simple method for purification of nucleic acids. J Clin Microbiol 28: 495-503.

CDC - Center for Disease and Control and Prevention 1995. Dengue type 3 infection - Nicaragua and Panama, October-November 1994. Morbity and Morbility Weekly Report 44: 21-24.

Chan S-Y, Kautner IM, Lam S-K 1994. The influence of antibody levels in dengue diagnosis by polymerase chain reaction. $J$ Virol Meth 49: 315-322.

Chungue E, Roche C, Lefreve M-F, Barbazan P, Chanteau S 1993. Ultra-rapid, simple, sensitive and economical silica method for extraction of dengue viral RNA from clinical specimens and mosquitoes by reverse transcriptase-polymerase chain reaction. J Med Virol 40: 142-145.

Deubel V, Laille M, Hugnot J-P, Chungue E, Guedson J-L, Drouet MT, Bassot S, Chevrier D 1990. Identification of dengue sequences by genomic amplification: rapid diagnosis of dengue virus serotypes in peripheral blood. J Virol Meth 30: 41-54.

Figueiredo LTM 1996. Dengue in Brazil I: history, epidemiology and research. Virus Rev Res 1: 9-16.

Figueiredo LTM, Owa MA, Carlucci RH, Oliveira L 1992. Estudo sobre diagnóstico laboratorial e sintomas do dengue, durante epidemia ocorrida na região de Ribeirão Preto, SP, Brasil. Rev Inst Med Trop São Paulo 34: 121-130.

Gubler DJ, Kuno G, Sather GE, Velez M, Oliver A 1984. Mosquito cell cultures and specific monoclonal antibodies in surveillance for dengue viruses. Am J Trop Med Hyg 33: 158-65.

Igarashi A 1978. Isolation of a Singh's Aedes albopictus cell clone sensitive to dengue and chikungunya viruses. J Gen Virol 40: 531-544.

Laille M, Deubel V, Sainte-Marie FF 1991. Demonstration of concurrent dengue 1 and dengue 3 infection in six patients by the polymerase chain reaction. $J$ Med Virol 34: 51-54.

Lanciotti RS, Calisher CH, Gubler DJ, Chang G-J, Vorndam V 1992. Rapid detection and typing of dengue viruses from clinical samples by using reverse transcriptase-polymerase chain reaction. J Clin Microbiol 30: 545-551.

Miagostovich MP, Nogueira RMR, Cavalcanti SMB, 
Marzochi KB, Schatzmayr HG 1993. Dengue epidemic in the state of Rio de Janeiro, Brazil: Virological and epidemiological aspects. Rev Inst Med Trop São Paulo 35: 149-154.

Morita K, Tanaka M, Igarashi A 1991. Rapid identification of dengue virus serotypes by using polymerase chain reaction. J Clin Microbiol 29: 2107-2110.

Morita K, Maemoto T, Honda S, Onishi K, Murata M, Tanaka M, Igarashi A 1994. Rapid detection of virus genome from imported dengue fever and dengue hemorrhagic fever patients by direct polymerase chain reaction. J Med Virol 44: 54-58.

Nogueira RMR, Miagostovich MP, Cavalcanti SMB, Marzochi KBF, Schatzmayr HG 1992. Levels of IgM antibodies against dengue virus in Rio de Janeiro, Brazil. Res Virol 143: 423-427

Nogueira RMR, Miagostovich MP, Lampe E, Schatzmayr HG 1990. Isolation of dengue virus type 2 in Rio de Janeiro. Mem Inst Oswaldo Cruz 85: 253.

Nogueira RMR, Miagostovich MP, Lampe E, Souza RW, Zagne SMO, Schatzmayr HG 1993. Dengue epidemic in the State of Rio de Janeiro, Brazil, 19901991: Co-circulation of dengue 1 and dengue 2. Epidemiol Infect 111: 163-170.

Pao CC, Yao D-S, Lin C-Y, King C-C 1992. Amplification of viral RNA for the detection of dengue types 1 and 2 virus. J Inf 24: 23-29.

Pearse AGE 1980. The chemistry and pratice of fixation, p. 97-158. In Histochemistry theoretical and applied. Vol 1, Churchill Livingstone, Edinburg.

Rosen L, Khin MM, U T 1989. Recovery of virus from the liver of children with fatal dengue: reflections on the pathogenesis of the disease and its possible analogy with that of yellow fever. Res Virol 140: 361-372.

Schatzmayr HG, Nogueira RMR, Rosa APAT 1986. An outbreak of dengue virus at Rio de Janeiro. Mem Inst Oswaldo Cruz 81: 245-246.

Seah CLK, Chow VTK, Tan HC, Chan YC 1995. Rapid, single-step RT-PCR typing of dengue viruses using five NS3 gene primers. J Virol Meth 51: 193-200.

Souza RV, Cunha RV, Miagostovich MP, Timbó MJ, Montenegro F, Pessoa ETFP, Nogueira RMR, Schatzmayr HG 1995. An outbreak of dengue in the state of Ceará, Brazil. Mem Inst Oswaldo Cruz 90: 345-346.

Vasconcelos PF, Menezes DB, Mello LP, Pessoa ETFP, Rodrigues SG, Montenegro F, Travassos da Rosa JF, Andrade FMO, Travassos da Rosa APA 1995. A large epidemic of dengue fever with dengue haemorrhagic cases in Ceará state, Brasil, 1994. Rev Inst Med Trop São Paulo 37: 253-255.

Vasconcelos PFC, Travassos da Rosa ES, Travassos da Rosa JFS, Freitas RB, Degallier N, Rodrigues SG, Travassos da Rosa APA 1993. Epidemia de febre clássica de dengue causada pelo sorotipo $2 \mathrm{em}$ Araguaina, Tocantins, Brasil. Rev Inst Med Trop São Paulo 35: 141-148.

Zagne SMO, Alves VGF, Nogueira RMR, Miagostovich MP, Lampe E, Tavares W 1994. Dengue haemorrhagic fever in the state of Rio de Janeiro, Brazil: a study of 56 confirmed cases. Trans $R$ Soc Trop Med Hyg 88: 677-679. 